\title{
МЕТАБОЛІЧНІ Й СТРУКТУРНІ ПОРУШЕННЯ МІОКАРДА В УМОВАХ ЕКСПЕРИМЕНТАЛЬНОГО ГОСТРОГО УРАЖЕННЯ ЛЕГЕНЬ
}

\begin{abstract}
Резюме. Вивчення метаболічних та структурних порушень міокарда в умовах експерименталного гострого ураження легень дає можливість розкрити патогенез процесів та спрогнозувати особливості перебігу при даній патології.

Мета дослідження - було з'ясувати динаміку показників пероксидного окиснення ліпідів, антиоксидантного захисту та патоморфологічних змін у серці в умовах експериментального гострого ураження легень.

Матеріали і методи. Дослідження виконано на білих безпородних щурах-самцях масою 200-220 г. Моделювання гострого ураження легень проводили за методикою G. Matute-Bello. Тварин виводили з експерименту через 12; 24; 48 та 72 год після моделювання гострого ураження легень. Для вивчення морфологічних змін використовували біоптати міокарда, зрізи яких були забарвлені гематоксиліном та еозином. У гомогенаті серця визначали показники пероксидного окиснення ліпідів (ПОЛ) та антиоксидантного захисту.

Результати досліджень та їх обговорення. При гострому ураженні легень, зумовленому інтратрахеальним введенням розчину хлоридної кислоти, у серці активуються процеси ліпідної пероксидації, про що свідчить накопичення ТБК-активних продуктів ПОЛ, з максимумом через 24 год (на 74,7 \% порівняно з контролем, p<0,05). За цих умов істотно знижуються показники ферментативної ланки антиоксидантного захисту з компенсаторним підвищенням понад контрольний рівень СОД через 48 год (на 88,3 \%, p<0,05), каталази - через 72 год (на 63,5 \%, p<0,05). За умов моделювання гострого ураження легень відмічаються структурі порушення міокарда з нерівномірним кровонаповненням судин через 12 год спостереження, фрормуванням клітинних інфрільтратів строми через 24 год, наростанням явищ парезу, еритростазів, набряку строми, вогнищевих дистросрічних змін кардіоміоцитів, дрібновогнищевої клітинної інсрільтрації через 48 год, появою еритро- та плазмостазів, поглибленням набряку, фррагментацією волокон та їх вогнищевою хвилеподібною десрормацією через 72 год.

Висновки. Наведені дані свідчать про системний патогенний вплив гострого ураження легень на організм піддослідних тварин, зокрема на серце з максимумом метаболічних порушень через 24 год і активацією механізмів компенсації через 4872 год.
\end{abstract}

Ключові слова: гостре ураження легень; серце; ліпідна пероксидація; антиоксидантний захист; морфологічні порушення.

ВСТУП Гостре ураження легень (ГУЛ) - поліетіологічне захворювання, зумовлене безпосереднім ушкодженням легеневої тканини при запаленні чи аспірації, або виникає вторинно при травмі чи сепсисі. Тяжким ускладненням ГУЛ є розвиток респіраторного дистрес-синдрому, який належить до основних причин смертності у відділеннях інтенсивної терапії [10].

Провідним патогенним механізмом ГУл $є$ розвиток некардіогенного набряку легень із формуванням системної гіпоксії та значна активація нейтрофрільних лейкоцитів з гіперпродукцією активних фрорм кисню та прозапальних цитокінів [7]. Нашарування цих механізмів поглиблює вторинне ураження органів і систем з фрормуванням синдрому поліорганної дисфункції і недостатності [12].

Важлива роль у патогенезі системного впливу ГУл відводиться активації процесів пероксидного окиснення ліпідів (ПОЛ) [2]. На цьому тлі при недостатності антиоксидантного захисту посилюється деструкція клітинних мембран паренхіматозних органів із втратою їх фрункцій, що замикає чергове "хибне" патологічне коло і поглиблює перебіг основного патологічного процесу. Однак закономірності пероксидного окиснення ліпідів у серці та розвиток у ньому патоморфологічних змін на тлі ГУЛ вивчено недостатньо, що значно обмежує доказовий підхід у розробці ефрективних заходів кардіопротекції.

Метою дослідження було з'ясувати динаміку показників пероксидного окиснення ліпідів, антиоксидантного захисту та патоморфологічних змін у серці в умовах експериментального ГУЛ.

МАТЕРІАЛИ І МЕТОДИ Експерименти проведено на 86 середньостійких до гіпоксії статевозрілих нелінійних щурах-самцях масою 200-220 г, яких утримували в стандартних умовах віварію. Для визначення стійкості до гіпоксії використовували методику В. Я. Бе- резовського [1]. Тваринам дослідної групи (68 особин) за методикою G. Matute-Bello [11] моделювання ГУл. 3 цією метою під тіопентал-натрієвим наркозом (40 мг.кГ-1) виконували цервікотомію, знаходили трахею. Тварин розміщували під кутом $45^{\circ}$ і на вдиху інсуліновим шприцом вводили розчин хлоридної кислоти $(\mathrm{pH}=1,2) 3$ розрахунку 1 мл·к $\Gamma^{-1}$ маси щура. Тваринам контрольної групи (18 особин) вводили фрізіологічний розчин в еквівалентній дозі.

3 експерименту тварин виводили за умов тіопенталнатрієвого знеболювання методом тотального кровопускання з серця: щурів дослідної групи - через 12; 24; 48 та 72 год після введення у трахею хлоридної кислоти, щурів контрольної групи - через 12 год після введення фрізіологічного розчину. Для дослідження забирали серце, з якого в однієї частини тварин дослідної і контрольної груп готували 10 \% гомогенат, в іншої - матеріал фріксували у 10 \% нейтральному фрормаліні для гістологічного дослідження.

У гомогенаті серця визначали концентрацію реагентів до тіобарбітурової кислоти (ТБК-активні продукти ПОЛ) [4], активність супероксиддисмутази (СОД) [9] і каталази [5], розраховували антиоксидантно-прооксидантний індекс (АПІ) за формулою: АПІ = каталаза / ТБК-активні продукти ПОЛ [3].

Зафріксовані шматочки серця ущільнювали в парафріні. Отримані на санному мікротомі зрізи фрарбували гематоксиліном та еозином й вивчали структуру досліджуваних тканин у нормі, а також характер і глибину морорологічних порушень після моделювання ГУл [8]. Застосовували світловий мікроскоп SEO SCAN. Мікропрепарати фотодокументували за допомогою відеокамери Vision CCD Camera, яка володіє системою виводу зображень гістологічних препаратів. 
Всі експериментальні дослідження виконано з дотриманням норм Європейської конвенції про захист хребетних тварин, що використовуються для досліджень та інших наукових цілей (Страсбург, 18.03.1986 р.) та постанови Першого національного конгресу з біоетики (Київ, 2001).

Отримані цифрові дані обробляли статистично. Вірогідність відмінностей між дослідними і контрольними групами оцінювали на основі непараметричного критерію Манна-Уїтні $з$ використанням програми STATISTICA (StatSoft, Inc., США).

РЕЗУЛЬТАТИ ДОСЛІДЖЕНЬ ТА ЇХ ОБГОВОРЕННЯ Як видно з таблиці 1, в умовах експериментального ГУЛ у серці піддослідних тварин упродовж 24 год суттєво посилювалися процеси ліпідної пероксидації. Вміст ТБКактивних продуктів ПОЛ через 12 год, порівняно з контролем, зростав на 67,4 \%, через 24 год - на 74,8\% $(p<0,05)$. В подальшому показник знижувався й через 48 год ставав статистично вірогідно меншим, ніж через 12 i 24 год $(p<0,05)$, проте перевищував контрольних щурів на $27,5 \%(p<0,05)$. Через 72 год показник досягав рівня контрольної групи ( $>>0,05)$ і був істотно меншим, ніж у попередні терміни спостереження $(p<0,05)$.

Активність СОД у серці на тлі моделювання ГУЛ до 12 год спостереження, порівняно з контролем, знижувалася на $36,3 \%(p<0,05)$, проте починаючи 324 год, показник зростав і через 48 год на 88,3 \% перевищував контрольних щурів $(p<0,05)$ та рівень попередніх термінів спостереження $(p<0,05)$. Через 72 год активність СОД у серці знижувалася і ставала на 28,5 \% меншою, ніж у контролі $(p<0,05)$, проте перевищувала рівень, зафріксований через 24 год спостереження $(p<0,05)$. У свою чергу, активність каталази, порівняно з контролем, змінювалася коливально: до 48 год показник поступово знижувався й досягав 32,6 \% від рівня контрольних щурів $(p<0,05)$. У цей період через 24 год відмічалася перша фаза підвищення показника, яка не досягала рівня контролю $($ < 0,05$)$. Через 72 год у серці наставала друга фраза підвищення активності каталази. Показник на 63,5 \% ставав більшим, ніж у контролі $(p<0,05)$, й у всі попередні терміни ГУЛ відповідно ( $p<0,05)$.

Аналізуючи сумарний антиоксидантно-прооксидантний баланс за величиною АПІ, встановили, що показник на тлі гУл через 48 год знижувався і був у 3,92 раза меншим, ніж у контролі ( $<<0,05)$. В цей період, як і за активністю каталази, через 24 год відмічалася перша фаза підвищення показника, який перевищував попередній термін спостереження $(p<0,05)$, проте не досягав рівня контролю й залишався у 2,59 раза меншим, ніж у контрольні $(p<0,05)$. Через 72 год відмічалася друга фраза підвищення активності показника. В цей термін він на 63,5 $\%$ перевищив рівень контрольних щурів $(p<0,05)$ і був статистично вірогідно більшим, ніж у попередні терміни спостереження ( $p<0,05)$ (табл.).

Аналіз патоморфологічних змін у серці в умовах моделювання ГУл показав, що через 12 год експерименту в структурі міокарда виникали незначні зміни (рис. 1). Хід м'язових волокон, інтенсивність їх пофрарбування, товщина кардіоміоцитів мало змінювались порівняно з контрольними тваринами. Саркоплазма залишалась гомогенною, ядра клітин чітко контуровані, видовжені були в усіх клітинах. Судинна реакція строми проявлялась порізному: в переважної більшості судин просвіти не розширювались, проте в товщі волокон виявлялись повнокровні капіляри. Паретичне розширення капілярів супроводжувалось периваскулярним набряком, який поширювався на перицелюлярні ділянки та поєднувався з дрібновогнищевими клітинними інорільтратами. Незначна частина судин спазмувалась, про що свідчили характерні зміни ендотеліоцитів.

Через 24 год 3 моменту моделювання гУл гістологічні зміни в міокарді поглиблювались. Вони переважали в системі кровопостачання (рис. 2). Просвіти судин дрібного калібру дещо розширювались, були виповненими еритроцитами. Периваскулярний набряк, порівняно 3 попереднім терміном спостереження, дещо зменшувався, проте збільшувалась клітинна інфільтрація строми. Структура кардіоміоцитів у даний термін спостереження візуально не змінювалась. Поперечна посмугованість волокон була збереженою, саркоплазма залишалась гомогенною. Ядра клітин були однотипними і спостерігались в усіх клітинах.

Через 48 год експерименту структурні зміни міокарда посилювалися. Так, нерівномірне кровонаповнення міокарда, яке виникало в попередній групі досліджень, змінювалось на виражене венозно-капілярне, в судинах дрібного калібру наростали явища парезу, які супроводжувались еритростазами та поєднувались помірним набряком строми (рис. 3). Частина кардіоміоцитів набухала, ставали безструктурними, ядра дещо зменшувались, просвітлювались. В ділянках таких змін з'являлась реактивна дрібновогнищева лейкоцитарна інфрільтрація.

Через 72 год експерименту в міокарді наростали гострі розлади кровообігу, збільшувалось венозно-капілярне повнокров'я (рис. 4). Порушувалися реологічні властивості крові, про що свідчили еритро- та плазмостази, які візуалізувались в розширених просвітах судин.

Дистонія переважної більшості судин призводила до нерівномірно вираженого набряку міжм'язової строми. Такі зміни підсилювали розвиток білкової зернистої дис-

Таблиця. Показники процесів ліпідної пероксидації та антиоксидантного захисту в гомогенаті серця через 12; 24; 48 та 72 год після моделювання гострого ураження легень $(\mathrm{M} \pm \mathrm{m})$

\begin{tabular}{|c|c|c|c|c|c|}
\hline \multirow[b]{2}{*}{ Показник } & \multirow[b]{2}{*}{$\begin{array}{l}\text { Контроль } \\
\quad(n=9)\end{array}$} & \multicolumn{4}{|c|}{ Гостре ураження легень } \\
\hline & & $\begin{array}{l}12 \text { год } \\
(\mathrm{n}=10)\end{array}$ & $\begin{array}{l}24 \text { год } \\
(\mathrm{n}=10)\end{array}$ & $\begin{array}{c}48 \text { год } \\
(\mathrm{n}=8)\end{array}$ & $\begin{array}{c}72 \text { год } \\
(\mathrm{n}=8)\end{array}$ \\
\hline ТБК-активні продукти ПОЛ (мкмоль· $\left.\Gamma^{-1}\right)$ & $1,572 \pm 0,039$ & $2,631 \pm 0,021^{*}$ & $2,746 \pm 0,004^{* 12}$ & $2,004 \pm 0,015^{* 12,24}$ & $1,506 \pm 0,086^{12,24,48}$ \\
\hline СОД (ум. од. $\left.\cdot \Gamma^{-1}\right)$ & $0,639 \pm 0,016$ & $0,407 \pm 0,005^{*}$ & $0,430 \pm 0,002^{* 12}$ & $1,203 \pm 0,005^{* 12,24}$ & $0,457 \pm 0,019^{* 12,48}$ \\
\hline Каталаза (мккат. $\left.\Gamma^{-1}\right)$ & $0,877 \pm 0,007$ & $0,522 \pm 0,001^{*}$ & $0,594 \pm 0,003^{* 12}$ & $0,286 \pm 0,004^{* 12,24}$ & $1,434 \pm 0,011^{* 12,24,48}$ \\
\hline АП। (ум. од.) & $0,560 \pm 0,012$ & $0,199 \pm 0,001^{*}$ & $0,216 \pm 0,001^{* 12}$ & $0,143 \pm 0,003^{* 12,24}$ & $0,985 \pm 0,083^{* 12,24,48}$ \\
\hline
\end{tabular}

Примітки: 1) * - відмінності стосовно контрольної групи статистично вірогідні $(p<0,05)$;

2) $12,24,48$ - відмінності стосовно 12; 24 і 48 год експерименту статистично вірогідні $(p<0,05)$. 


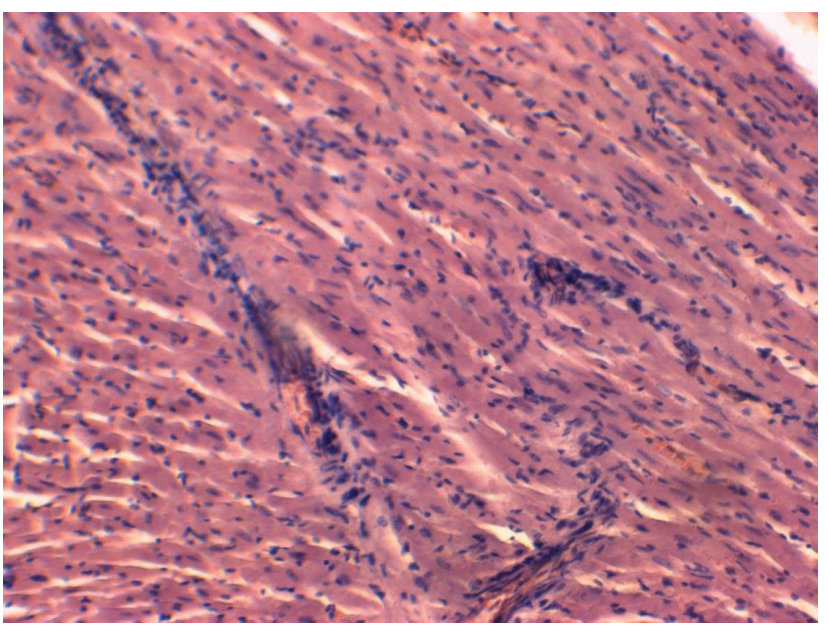

Рис. 1. Спазм судини міокарда та формування вогнищевих клітинних інфільтратів через 12 год експерименту. Забарвлення гематоксиліном та еозином. $\times 100$.

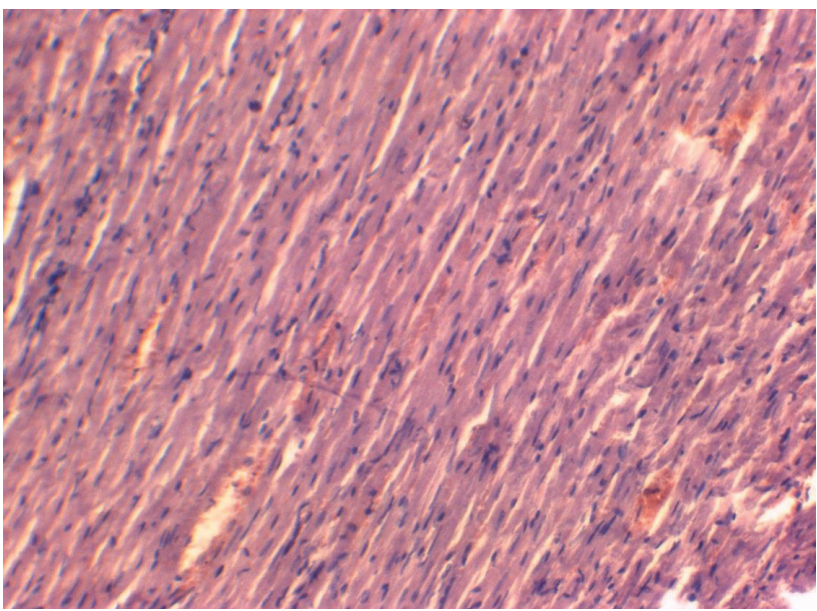

Рис. 3. Венозно-капілярне повнокров'я, паретично розширені судини, еритростази судин міокарда через 48 год експерименту. Забарвлення гематоксиліном та еозином. ×100.

тросрії кардіоміоцитів, яка проявлялась вогнищевою вираженою гіпертрофрією та слабовираженим стоншенням окремих волокон. В окремих полях зору мала місце фррагментація м'язових волокон як ознака можливого порушення ритму, та явища хвилеподібної десормації (рис. 5).

Таким чином, моделювання ГУЛ супроводжується посиленням ліпідної пероксидації в серці з максимумом через 24 год і наступним зниженням до рівня контролю через 72 год. Отриманий результат зумовлений посиленням гіпоксії унаслідок ушкодження тканин легень після введення хлоридної кислоти та активацією нейтрофрілів. Максимум порушення кисневого балансу і накопичення активних форм кисню відмічається саме через 24 год після моделювання гул [6]. Очевидно, ці механізми зумовлюють посилення процесів ліпопероксидації в серці.

Починаючи 348 год, у серці компенсаторно зростає активність СОД, а з 72 год - каталази, які сприяють нормалізації вмісту ТБК-активних продуктів ПОЛ. Про домінування саногенних механізмів через 72 год красномовно свідчить величина АПІ, яка суттєво перевищувала не

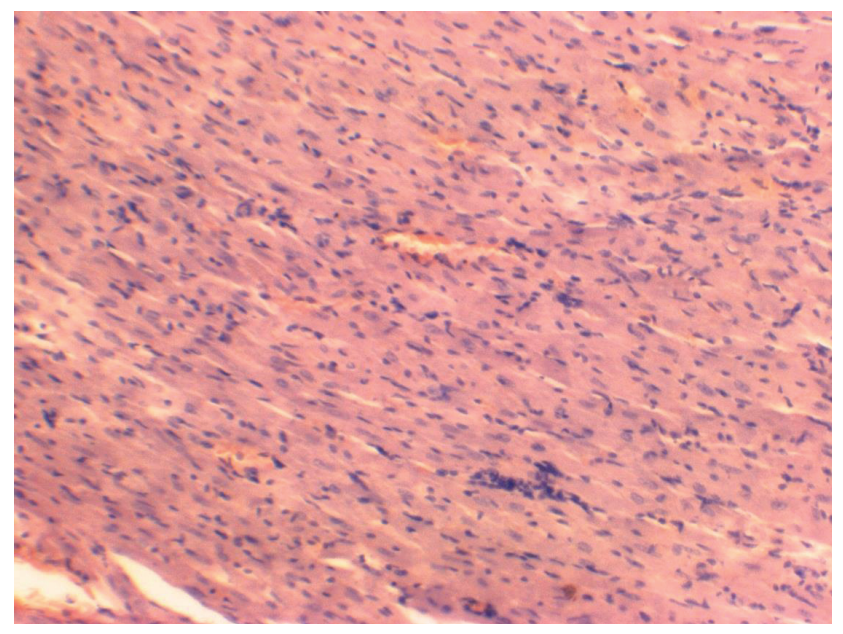

Рис. 2. Дрібновогнищеві клітинні інфрільтрати в міокарді через 24 год експерименту. Забарвлення гематоксиліном та еозином. $\times 100$.

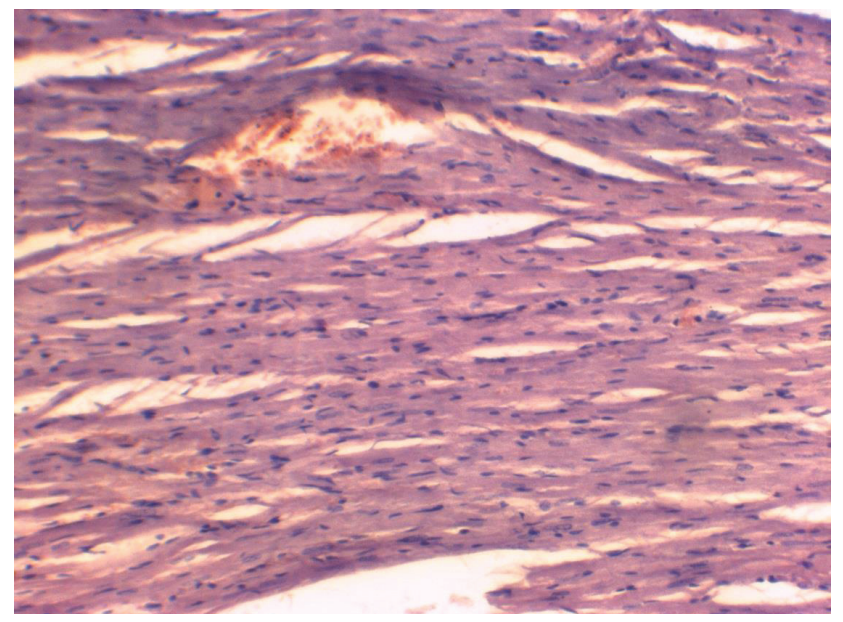

Рис. 4. Набряк міжм'язової строми міокарда через 72 год експерименту. Забарвлення гематоксиліном та еозином. ×100.

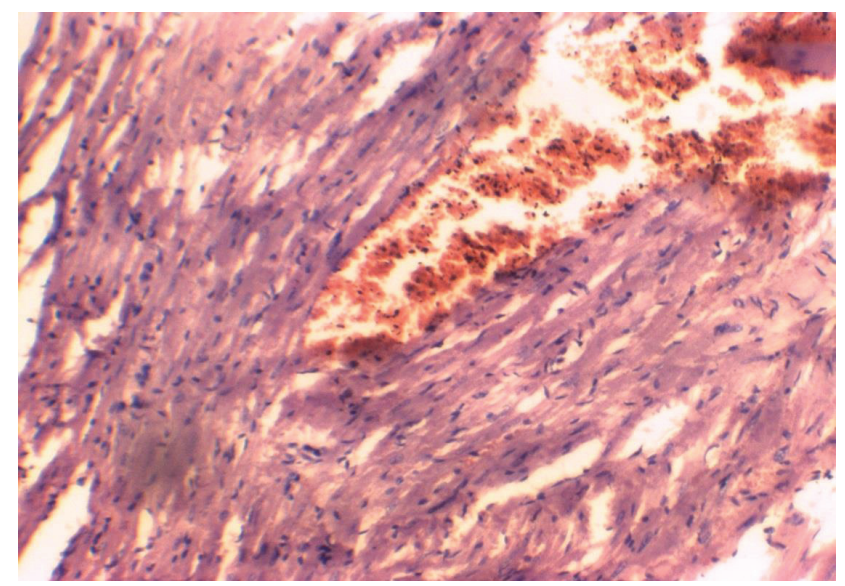

Рис. 5. Еритростази в розширених судинах, фрагментація м'язових волокон міокарда через 72 год експерименту. Забарвлення гематоксиліном та еозином. $\times 100$. 
тільки попередні терміни спостереження, але й контрольний рівень.

Відповідно до біохімічних порушень серця наростали його структурні зміни. Так 312 год спостерігалось нерівномірне кровонаповнення судин міокарда, яке з 24 год проявлялось формуванням клітинних інорільтратів строми, 348 год в дрібних судинах міокарда наростали явища парезу, що призводило до еритростазів, набряку строми, вогнищевих дистрофічних змін кардіоміоцитів, дрібновогнищевої клітинної інфрільтрації. Через 72 год розлади кровообігу супроводжувались еритро- та плазмостазами, поглибленням набряку, фрагментацією волокон та їх вогнищевою хвилеподібною деформацією. Виявлені структурні порушення в серці зумовлені патогенним впливом ГУЛ на міокард. Звертає на себе увагу той фракт, що покращення метаболічних порушень в міокарді явно випереджають відновлення його структурних змін.

Наведені дані свідчать про системний патогенний вплив ГУЛ на організм піддослідних тварин, зокрема на серце 3 максимумом метаболічних порушень через 24 год і активацією механізмів компенсації через 48-72 год. Протягом цього терміну наростають структурні зміни мі- окарда. Отримані результати слід враховувати при розробці патогенетично обґрунтованих засобів корекції.

ВисновкИ 1. При гострому ураженні легень, зумовленому інтратрахеальним введенням розчину хлоридної кислоти, у серці активуються процеси ліпідної пероксидації, про що свідчить накопичення ТБК-активних продуктів ПОЛ, 3 максимумом через 24 год. За цих умов істотно знижуються показники фрерментативної ланки антиоксидантного захисту з компенсаторним підвищенням понад контрольний рівень СОД через 48 год, каталази - через 72 год.

2. За умов моделювання ГУл відмічаються структурі порушення міокарда з нерівномірним кровонаповненням судин через 12 год спостереження, фрормуванням клітинних інорільтратів строми через 24 год, наростанням явищ парезу, еритростазів, набряку строми, вогнищевих дистрофрічних змін кардіоміоцитів, дрібновогнищевої клітинної інфрільтрації через 48 год, появою еритро- та плазмостазів, поглибленням набряку, фррагментацією волокон та їх вогнищевою хвилеподібною десормацією через 72 год.

Перспективи подальших досліджень У перспективі доцільно б провести апробацію засобів з кардіопротекторною дією в умовах експериментального ГУЛ.

\section{СПИСОК ЛІТЕРАТУРИ}

1. Березовский В. А. Гипоксия и индивидуальные особенности реактивности / В. А. Березовский. - К. : Наукова думка, 1978. $216 \mathrm{c}$.

2. Грищук Л. А. Динаміка перекисного окиснення ліпідів та антиоксидантного захисту в щурів при гострому ураженні легень / Л. А. Грищук, М. І. Марущак // Туберкульоз, легеневі хвороби та ВІЛ-інфрекція. - 2011. - № 1. - С. 16-20.

3. Экспериментальные методы исследования стимуляторов остеогенеза: методические рекомендации / А. П. Левицкий, О. А. Макаренко, О. В. Деньга [и др.]. - К. : ГФЦ МЗ Украины "Авиценна", 2005. - С. 31-38.

4. Коробейникова Э. Н. Модификация определения продуктов ПОЛ в реакции с тиобарбитуровой кислотой / Э. Н. Коробейникова // Лабораторное дело. - 1989. - № 7. - С. 8-10.

5. Метод определения активности каталазы / М. А. Королюк, Л. И. Иванова, И. Г. Майорова [и др.] // Лабораторное дело. 1988. - № 1. - С. 16-19.

6. Марущак М. І. Роль активних форм кисню у розвитку і прогресуванні гострого ураження легень в експерименті / М. І. Марущак // Медична та клінічна хімія. - 2012. - Т. 14, № 1. С. 104-108.

7. Патогенна роль нейтрофрільних гранулоцитів у розвитку гострого ураження легень / А. А. Гудима, М. І. Марущак, Г. Г. Габор, М. І. Каліцька // Буковинський медичний вісник. 2011. - № 3. - C. 82-84.

8. Сапожников А. Г. Гистологическая и микроскопическая техника : руководство / А. Г. Сапожников, А. Е. Доросевич. Смоленск : САУ, 2000. - 476 с.

9. Чевари С. Роль супероксидредуктазы в окислительных процессах клетки и метод определения ее в биологическом материале / С. Чевари, И. Чаба, Й. Секей // Лаб. дело. - 1985. - № 11. - С. 678-681.

10. Johnson E. R. Acute lung injury: epidemiology, pathogenesis, and treatment / E. R. Johnson, M. A. Matthay // J. Aerosol. Med. Pulm. Drug Deliv. - 2010. - Vol. 23(4). - P. 243-252.

11. Matute-Bello G. Animal models of acute lung injury [Text] / G. Matute-Bello, C. W. Frevert, T. R. Martin // American Journal Phisiology. - 2008. - Vol. 295, Issue 3. - P. 379-399. doi: 10.1152/ ajplung.00010.2008

12. Predictive and pathogenetic value of plasma biomarkers for acute kidney injury in patients with acute lung injury / K. D. Liu, D. V. Glidden, M. D. Eisner [et al.] // Crit. Care Med. - 2007. Vol. 35. - P. 2755-2761.

Отримано 07.06.17

\section{METABOLIC AND STRUCTURAL MYOCARDIAL DISEASE IN THE CONDITIONS OF EXPERIMENTAL ACUTE LUNG INJURY}

Summary. The study of metabolic and structural myocardial disorders in conditions of experimental acute lung injury allows revealing the pathogenesis of processes and predicting the peculiarities of the course in this pathology.

The aim of the study - to find out the dynamic indicators of peroxide lipid oxidation, antioxidant protection and pathomorphological changes in the heart under conditions of experimental state lung injury.

Materials and Methods. Experiments were conducted on white nonlinear male-rats weighing 200-220 g. Modeling of acute lung injury was performed according to the method of G.Matute-Bello. Animals were excised from the experiment at $12,24,48$ and 72 hours after the simulation of acute lung injury. To study morphological changes, myocardial biopsies were used, the sections of which were stained with hematoxylin and eosin. In the heart homogenate established indicators of lipid peroxidation and antioxidant protection. 
Results and Discussion. In the acute lung injury due to intracutaneous administration of chloride acid, the processes of lipid peroxidation are activated in the heart, as evidenced by the accumulation of TBA-active products of the LPO, with a maximum of 24 hours (by $74.7 \%$ compared with the control, $p<0.05$ ). Under these conditions, the indexes of the enzymatic level of antioxidant defense with a compensatory increase above the control level of SOD in 48 hours (by $88.3 \%, p<0.05$ ), catalase after 72 hours (by $63.5 \%$, $\mathrm{p}<0.05)$. Under the conditions of modeling of acute lung injury, the structure of myocardial damage with uneven blood filling of blood vessels in 12 hours of observation, the formation of cellular infiltrates of stroma in 24 hours, an increase in paresis phenomena, erythrostasis, stroke edema, focal dystrophic changes in cardiomyocytes, small focal cell infiltration after 48 hours, appearance erythro- and plasmapostasis, deepening of edema, fragmentation of fibers and their focal wave-like deformation after 72 hours.

Conclusions. The given data testify to the systemic pathogenic effect of acute lung injury on the organism of experimental animals, in particular on the heart with a maximum of metabolic disturbances in 24 hours and the activation of compensation mechanisms in 48-72 hours.

Key words: acute lung injury; heart; lipid peroxidation; antioxidant defense; morphological disorders.

(с). О. Костина, А. А. Гудыма, Т. В. Дацко

ГВУЗ “Тернопольский государственный медицинский университет имени И. Я. Горбачевского”

\section{МЕТАБОЛИЧЕСКИЕ И СТРУКТУРНЫЕ НАРУШЕНИЕ МИОКАРДА В УСЛОВИЯХ ЭКСПЕРИМЕНТАЛЬНОГО ОСТРОГО ПОРАЖЕНИЯ ЛЕГКИХ}

Резюме. Изучение метаболических и структурных нарушений миокарда в условиях экспериментального острого поражения легких дает возможность раскрыть патогенез процессов и спрогнозировать особенности течения заболевания при данной патологии.

Цель исследования - выяснить динамику показателей перекисного окисления липидов, антиоксидантной защиты и патоморфологических изменений в сердце в условиях экспериментального острого поражения легких.

Материалы и методы. Исследования выполнены на белых беспородных крысах-самцах массой $200-220$ г. Моделирование острого поражения легких проводили по методике G. Matute-Bello. Животных выводили из эксперимента через 12; $24 ; 48$ и 72 ч после моделирования острого поражения легких. Для изучения морфологических изменений использовали биоптаты миокарда, срезы которых были окрашены гематоксилином и эозином. В гомогенате сердца определяли показатели перекисного окисления липидов (ПОЛ) и антиоксидантной защиты.

Результаты исследований и их обсуждение. При остром поражении легких, обусловленном введением интратрахеального раствора соляной кислоты, в сердце активируются процессы липидной пероксидации, о чем свидетельствует накопление ТБК-активных продуктов ПОЛ, с максимумом через 24 ч (на 74,7 \% по сравнению с контролем, р<0,05). В этих условиях существенно снижаются показатели фрерментативного звена антиоксидантной защиты с компенсаторным повышением более контрольного уровня СОД через 48 ч (на 88,3 \%, p<0,05), каталазы - через 72 ч (на 63,5 \%, p<0, 05). В условиях моделирования острого поражения легких отмечаются структурные нарушения миокарда с неравномерным кровенаполнением сосудов через 12 ч наблюдения, формированием клеточных инфильтратов стромы через 24 ч, нарастанием явлений пареза, эритростазов, отека стромы, очаговых дистрофических изменений кардиомиоцитов, мелкоочаговой клеточной иноильтрации через 48 ч, появлением эритро- и плазмостазов, увеличением отека, фрагментацией волокон и их очаговой волнообразной деорормацией через 72 ч.

Выводы. Приведенные данные свидетельствуют о системном патогенном влияние острого поражения легких на организм подопытных животных, в частности на сердце с максимумом метаболических нарушений через 24 ч и активацией механизмов компенсации через 48-72 ч.

ключевые слова: острое поражение легких; сердце; липидная пероксидация; антиоксидантная защита; морфологические нарушения. 